\title{
Marian Movements and Secessionist Warfare in Bougainville, Papua New Guinea
}

\section{Anna-Karina Hermkens}

\begin{abstract}
This article focuses on the enigma of Catholic Marian revolutionary movements during the decade-long conflict on the island of Bougainville, Papua New Guinea at the end of the twentieth century. These religious movements embody the legacy of a colonial history as well as people's responses to poorly monitored resource extraction, social and economic displacement, regional factionalism, and years of fighting by Bougainvilleans against the Papua New Guinea Defence Force. At the same time, the movements' popularity throve on leaders' reputations for their religious knowledge and their mobilization of people based on religious faith. During the conflict Bougainville came to be seen by many residents as holy land (Me'ekamui). According to Francis Ona's Marian Mercy Mission and Peter Kira's Our Lady of Mercy movements, the covenant land of Bougainville had to be safeguarded from Satan, represented by Papua New Guinea and an Australian copper mining company, in the freedom struggle conceived as a Marian holy war.
\end{abstract}

KEYWORDS: Bougainville, Marian movements, Francis Ona, Marian Mercy Movement, Peter Kira, Our Lady of Mercy

$\mathrm{F}$ rom 1988 until 1998 Bougainville Island (see Figure 1), the easternmost province of Papua New Guinea (PNG), was the stage of brutal warfare, which caused great suffering and ruined nearly all infrastructure and socio-economic services. The crisis revolved around the exploitation by one of the world's largest copper mines, located in

Nova Religio: The Journal of Alternative and Emergent Religions, Volume 18, Issue 4, pages 35-54. ISSN 1092-6690 (print), 1541-8480. (electronic). (C) 2015 by The Regents of the University of California. All rights reserved. Please direct all requests for permission to photocopy or reproduce article content through the University of California Press's Rights and Permissions website, at http://www.ucpressjournals.com/reprintinfo.asp. DOI: $10.1525 / \mathrm{nr} .2015 .18 .4 .35$. 


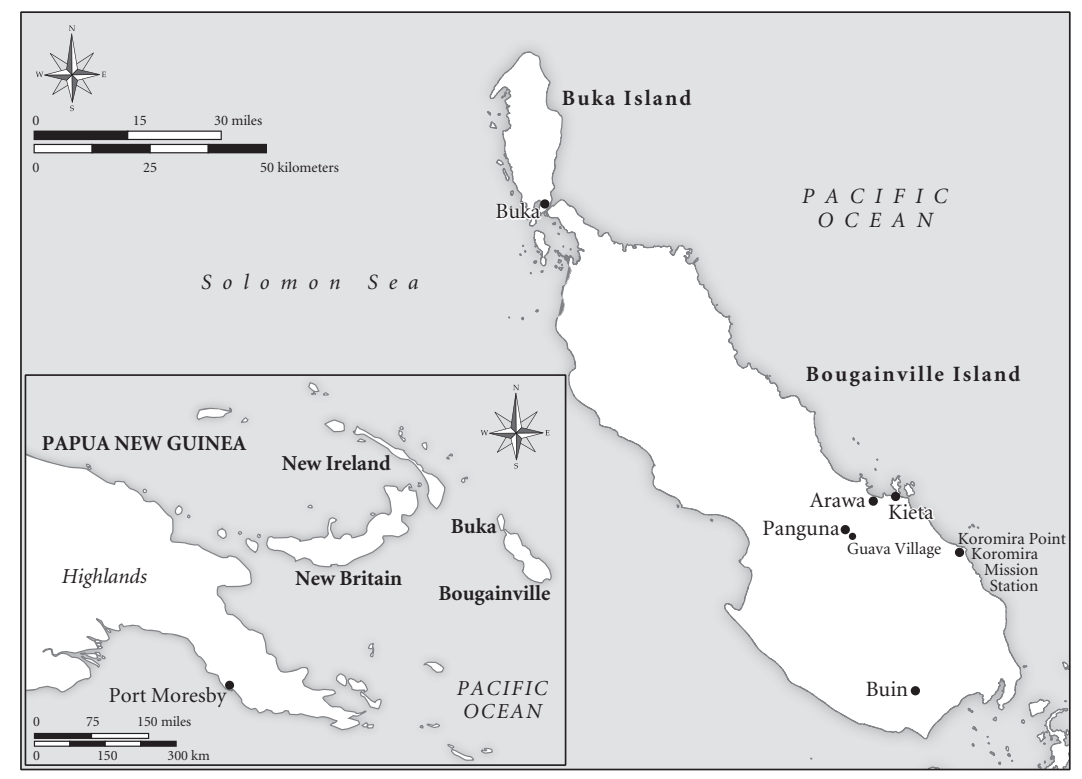

Figure 1. Map of Bougainville by George Chakvetadze. Used by permission of Oxford University Press.

the island's central mountain range near the village of Panguna in the Koromira area. Beginning in 1972 Bougainville Copper Ltd. (BCL) operated the Panguna mining project of Conzinc Riotinto of Australia, but the project faced increasing local resistance. Francis Ona (c. 1953-2005), a former BCL employee, led the protest in the 1980s and 1990s. He and his sister ${ }^{1}$ demanded ten billion kina (roughly 2.4 billion euros) in compensation for damage to the land and environment, ${ }^{2}$ but the mining company ridiculed this demand. Angry at Bougainville Copper Ltd.'s response, Francis Ona and his group, which would become known as the Bougainville Revolutionary Army (BRA), sabotaged a power line pylon, thereby cutting off power to the Panguna mine. ${ }^{3}$ This militant action in November 1988 was followed by other sabotages that shut down mining operations. Since BCL was the nation's largest employer and provided almost half of PNG's export earnings, the mine closure meant financial disaster for both Bougainville and Papua New Guinea. ${ }^{4}$ The PNG government mobilized the Papua New Guinea Defence Force (PNGDF) to protect the mine and bring the BRA under control.

The Panguna mine incident increased prevailing desires in the Bougainville population for freedom and self-governance. Experiences with colonial oppression had led to resentment and resistance, ${ }^{5}$ and Bougainvilleans were not keen on becoming a PNG province when 
Papua New Guinea gained independence from Australia. Despite various efforts and claims of independence, however, Bougainville Island became part of independent Papua New Guinea on 16 September 1975, an annexation that resulted in uprisings against the national government. Ensuing negotiations could not erase the frustration and resentment against PNG, leaving many Bougainvilleans with an enduring feeling of being "the neglected district" of Papua New Guinea. ${ }^{6}$ They complained that only two percent of the Panguna mine's revenue came back to Bougainville, with PNG taking the largest profit share and denying infrastructure development for Bougainville. In addition, they blamed Bougainville Copper Ltd. for hiring outside employees instead of giving more jobs to Bougainvilleans. Hiding in the mountains from the PNGDF, Francis Ona united with Damien Dameng's secessionist movement, Me'ekamui Pontoko Onoring (roughly, "government of the guardians of the sacred land"), which provided a spiritual rationale for their resistance. ${ }^{7}$ This merger altered Ona's militancy from mainly antiBCL sabotage to support for secession of Bougainville Island from Papua New Guinea. ${ }^{8}$

After almost ten years of warfare, 15,000 deaths (approximately 10 percent of the population), and numerous broken peace agreements, the crisis ended with the 1998 signing of the Ceasefire and the August 2001 Peace Agreement. ${ }^{9}$ Under the agreement, Bougainville became the Autonomous Region of Bougainville of Papua New Guinea, with a referendum on independence to be held within the near future. The first election for the Autonomous Government and President was held in 2005. Ona and his BRA/Me'ekamui followers, however, remained outside these agreements. For Ona, Bougainville already was independent, with its own Government of Me'ekamui. In fact, in May 2004 Ona proclaimed himself as king of the Royal Kingdom of Me'ekamui.

Surprisingly, consideration of the religious outlook of the revolutionaries is virtually absent in major studies of the conflict. ${ }^{10}$ Simon Kenema, a Bougainvillean scholar, has criticized analyses that omit consideration of indigenous cosmologies, arguing that comprehension of how and why the conflict took place requires knowledge of preexisting systems of cultural logic. ${ }^{11}$ To that end, I focus here on two Marian movements active during the crisis: Francis Ona's Marian Mercy Mission (MMM) and Peter Kira's Our Lady of Mercy (OLM). Both movements labeled the fight against PNG a holy war and sought to transform Bougainville into one, holy, Catholic nation, opposing Papua New Guinea and the autonomous status PNG ultimately granted to Bougainville Island. Members of both movements placed themselves and Bougainville within the main doctrine of the Catholic Church, which professes belief in "one, holy, catholic [universal] and apostolic Church." Although this statement in the Nicene Creed is not currently taught by the Roman Catholic Church as implying a mandate for Roman Catholic dominion 
over all Christians, members of the OLM and MMM movements interpreted this statement as mandating a pan-Catholic population in Bougainville. $^{12}$

While relatively small, the two Marian movements discussed here had significant ideological and political impacts on Bougainville. In the Koromira area, the Our Lady of Mercy movement and the Marian Mercy Mission shaped the local BRA's spiritual and political ideology and the quest to create one, holy, Catholic Bougainville nation. Both movements supported and cultivated BRA's struggle for independence from an exploitative Papua New Guinea and outside interference. Both envisioned the struggle against PNG and Australian hegemony as a holy war to restore Bougainville to the unblemished holy island it once was. Both movements were shaped by a strongly localized Catholic discourse in which devotion to the Virgin Mary was central. Their religious ideologies constituted a form of ethno-nationalism with fierce anti-foreign sentiments and the notion of a traditional customary society. Thus Mary and God as taught by Catholicism were appropriated in an "ideology of resistance." 13 This political aspect of Marian devotion is prominent in other parts of the world, such as Poland where Mary has been a powerful symbol against oppression throughout that country's history. ${ }^{14}$ In Bougainville, Mary became intertwined with an ideology of resistance, which ultimately was focused on the empowerment of an individual's political leadership, that of Francis Ona.

\section{FRANGIS ONA, MARIAN DEVOTION AND HOLINESS}

The task of saving Bougainville from foreign oppression and exploitation had fallen to the Bougainville Revolutionary Army. Especially for Naisioi people living in the Koromira area, where I did most of my ethnographic research between October 2005 and January $2006,{ }^{15}$ the BRA acted as a holy army, guided by Francis Ona and supported by God and the Virgin Mary, to restore Bougainville to what it once was: me'ekamui — a holy island-where ancestors are believed to reside. In the past each village appointed a caretaker of sacred places, including stones, trees and rivers, which worshippers visited to make offerings, pray for a good harvest, give thanks, pray for a return to health, and so forth. This vision of Bougainville as a sacred land was promulgated particularly in the Koromira area and by supporters of the Me'ekamui movement.

Damien Dameng initiated Me'ekamui Pontoko Onoring around 1959 to champion Bougainvillean culture while strongly opposing the presence and influence of foreign cultures. This opposition to outsiders and colonialists was evident also in other new religious movements emerging around this time, such as the Hahalis Welfare Society on Buka Island (north of Bougainville Island), which refused to pay colonial taxes, 
initiated the breakdown of traditional sexual taboos and rejected mission constraints. ${ }^{16}$ Although rejecting outside influences, Dameng did embrace some Christian elements. In fact, "by rejecting 'bad' aspects of custom, and building in some 'good' aspects of the changes brought by the missions and the colonial administration," 17 the movement built something new. Adherents, however, believed their social structure was built mainly upon custom, and with Dameng they opposed both colonial administration and Christian missions, regarding their own custom to be superior. ${ }^{18}$ According to Garry Trompf, "Damen's followers, including Ona, were encouraged to maintain a Catholic 'front' but they were to preserve traditionalist principles in secret...." ${ }^{19}$ Francis Ona's concept of Bougainville as holy land was similar to that of Dameng, but Ona saw Bougainville's salvation and future not only in custom but also, and perhaps more strongly, in Catholic belief and devotion especially to Mary. As former BRA combatants and members of Ona's Marian Mercy Mission movement stated to me, Ona was convinced that if Bougainville was to become holy again, Bougainvilleans and especially their leaders would have to become holy. Catholicism and particularly veneration of Mary played a crucial part in this quest.

The central role of Mary in Ona's ideology comes as no surprise when one considers the prominence of the Catholic Church and, in particular, the Society of Mary in Bougainville. European and subsequently American and Australian Marist missionaries introduced Catholicism to the island beginning in $1901 .^{20}$ In 2000, 69 percent of roughly 180,000 Bougainvilleans were Catholic, followed by United Church (15 percent), ${ }^{21}$ Seventh-day Adventist (7 percent) and Pentecostal (6 percent). ${ }^{22}$ Due to the missionaries' zeal the Marist spirit spread throughout Bougainville. ${ }^{23}$ For some islanders, the matrilineal system and traditional gender relations may have supported this Marian movement. Traditionally in Bougainville societies, women have been caretakers of the land inherited via the female line. While sharing leadership responsibilities with men, women traditionally have fielded requests from children desiring something from their fathers. Like Mary, women have played a mediating role in Bougainville culture. ${ }^{24}$

The importance of Mary in the lives of many Bougainvilleansbefore, during and after the crisis—can be seen among the influences of Marist priests, Brothers and Sisters on peoples' spiritual mindsets. More recent Marist teachings have inspired influential Bougainvilleans to oppose successive acts of oppression, ${ }^{25}$ encouraging them to reject colonial or postcolonial oppression and strive for self-determination and political leadership. When Panguna villagers opposed mining prospecting on their lands "from the early 1960s onwards, some of the Marist priests became involved in the enduring dispute and encouraged the people to be firm in standing up for their rights." 26 Significantly, Ona was right in the middle of these events. 


\section{Nova Religio}

At the time of the prospecting activities, Francis Ona-a young Nasioi from Guava village next to the Panguna mine-was attending the Tunuru Catholic Mission school near Arawa, close to Kieta, the traditional capital of Bougainville. In 1968 he continued his Marist education at Saint Joseph Rigu High School at Rigu Lagoon. ${ }^{27}$ While he was at Rigu, a confrontation took place between Panguna landowners and the mining company over survey pegs marking the boundaries of the mine leases. The police riot squad arrested some villagers from Guava and surrounding villages who later were imprisoned at Kieta. In protest, local landowners called their children home from the schools. According to Lawrence Daveona, Ona (who was his cousin) was one of the students, but realizing his education was more important he returned to Rigu to continue his studies. After completing high school Ona attended and graduated from the University of Technology, Lae (on mainland PNG), and in 1976 joined Bougainville Copper Ltd. as a surveyor. ${ }^{28}$ He became a member of the young Bougainville mineworkers and the New Panguna Landowners Association (NPLA), which mistrusted and opposed the older Panguna Landowners Association. ${ }^{29}$ Ona emerged as a key NPLA leader who voiced commonly shared grievances against BCL. When in March-April 1988 this new association demanded an adjusted and increased compensation package, ${ }^{30}$ Ona led a group of young mineworkers in committing sabotage against the BCL.

\section{ONA'S MARIAN MERCY MISSION}

To what extent did Marist teachings influence Ona's religious and political thinking? Bishop Henk Kronenberg, S.M., the Dutch bishop of Bougainville from 1999 to 2009, stated that Ona had been particularly devoted to Mary. ${ }^{31}$ During the crisis Ona sought her advice before a statue of Mary and would proceed with his daily agenda only after receiving her confirming message. Ona's devotion to Mary was expressed in the Marian movement he initiated in Guava village, near the Panguna mine. In 1993 Ona established the Marian Mercy Mission (MMM), with himself as Superior. Devotees would recite the rosary for hours and regularly engage in fasting and prayer. When Ona asked Guava villagers to pray for a name for their prayer group, the name Marian Mercy Mission emerged. ${ }^{32}$ The movement had women's and youth groups, church workers and catechists, but they wanted a priest to give blessings and Communion. Father Luis Lovosi and another priest, who had taught Ona at Rigu High School, went to Guava during the crisis to give prayer retreats and say Mass. ${ }^{33}$ After the 1994 ceasefire, ${ }^{34}$ Bishop Kronenberg went to Guava to consecrate the Marian Mercy Mission, which obviously provided a huge impetus to the legitimacy and success of the movement. ${ }^{35}$ The Marian Mercy Mission is now credited with 
keeping the Catholic faith alive, especially in Guava village. In 2005 Father Bernard Unabali, since 2009 the current Catholic bishop of Bougainville, described the MMM as a very strong movement that emphasizes morality and strives for the conversion of all Bougainvilleans to Catholicism. ${ }^{36}$

One of the main aims of the Marian Mercy Mission was to pray and help others. Participants prayed for healing, protection, goods and food, and, most importantly, independence. In fact, Ona and others received strength from MMM devotional activities to strive for self-determination and freedom. ${ }^{37}$ As narrated by Maria Dewana from Guava, who became an MMM member in 1993:

Ona had visions of Mary talking to him. She was telling him to inform people that they have to change. Everyone had to become holy. He foresaw through Mary what would happen in the future. Ona was a man of prayer. He committed himself to prayer so the result would be independence. The whole Marian Mercy Mission committed themselves to these ideals. Ona's dream was for the whole of Bougainville to come inside this Lotu [Church/religion] and become independent. Santu Maria helped us in our struggle for independence. She protected us. The Marian Mercy Mission prayed to Maria for help, for cargo and money from America or other countries.... Santu Maria has been giving many things to Francis Ona. It was Santu Maria and God who chased out all these big mining companies. It was with her help that this was made possible. Santu Maria was very close to Francis Ona. ${ }^{38}$

The interplay between Ona's Bougainvillean nationalism and his devotion to Mary came to the fore in 1997 when he extended a warm welcome to the Pilgrim Virgin Statue of Our Lady of Fatima to Guava village. ${ }^{39}$ Pilgrimage organizers and the village faithful believed that Ona was convinced by Mary to stop the fighting. ${ }^{40}$ A Catholic missionary priest captured the proceedings on film, and on these never-released recordings ${ }^{41}$ Ona can be seen and heard making a vow to Our Lady of Fatima to work toward peace. More significantly, Ona consecrated the island of Bougainville to Mary, appropriating the whole of Bougainville in her name.

\section{PETER KIRA'S OUR LADY OF MERGY}

During the crisis Mary became increasingly popular all over Bougainville, resulting in devotional groups and religious movements such as the Marian Mercy Mission. One movement-Our Lady of Mercy-seems to have been particularly influential and supportive of Ona's political goal. ${ }^{42}$ Two years after the crisis started, Bougainville was immersed in a political and economic vacuum, with almost no civil government, a total blockade, and casualities caused by the PNGDF and 


\title{
Nova Religio
}

the BRA. In this environment 50-year-old Peter Kira, from the Nasioi village of Kokoka in Koromira Parish, founded the OLM to do "the work of Mama Maria." 43 Aided by a small statue of Our Lady of the Immaculate Conception he had bought on Buka Island before the crisis, and the rosaries given to him by Bishop Gregory Singkai, the first local bishop appointed in Bougainville (in 1974), ${ }^{44}$ Kira shared his message about Mary and tried to convert Seventh-day Adventists and Methodists to Catholicism.

Kira had been called by Mary in 1986, when he was about to start a special home for the sick:

\begin{abstract}
At 11 o'clock p.m., somebody talked to me: "Don't expect to raise funding, you must call this work the work of Mama Maria, Our Lady of Mercy." So I started this work of helping others for free. I resigned as a schoolteacher and focused on this work. I started healing bone fractures and many other diseases. I advised people, sharing the good news with them, helping them spiritually. Many times I would send people to the priest with an accompanying letter for them to have confidence in the Lord and Mary. I would pray to Jesus and Mary, asking them to have pity with the sick person and help him or her to get well. After praying, people would get better and I see this as the straightforward power of Mary.... During the crisis, I went to all villages, teaching people about Santu Maria. I showed them three things: Incarnation, Passion and Resurrection. . . . I showed them Immaculate Conception as Our Lady of Mercy, telling them, Mary has no sin. I told them to pray the rosary, as the main part of this devotion is the rosary and the promises of the rosary. "If you have problems, pray the rosary and Mary will hear you." I went around all the time, carrying this small statue of the Immaculate Conception. ${ }^{45}$
\end{abstract}

Inspired by Kira's work of healing and conversion, others started to follow him in the work of Mary. One was Ichnatus Denkiung, who was the Koromira Parish chair when I met him in 2005. He recalled being "set straight" from his bad habits and cured from chronic illness through Peter Kira. Denkiung's behavior and life started to change in 1986 after he attended a large penitance gathering at Koromira mission station organized by Kira. But real transformation occurred in 1991 after he spent a week in prayer with Kira. "I didn't know how to pray, but he prayed with me, told me to pray the rosary and he gave me bush medicine [to heal Denkiung's appendix]. Slowly, through Santu Maria, I healed and changed my attitude." 46 At the same time, Kira developed the Our Lady of Mercy movement into an official society. Denkiung recalled, "It was clear to all that Peter worked with the Holy Spirit and with Santu Maria." 47

The OLM movement was acknowledged by Bishop Singkai, as well as the Bougainville Revolutionary Army and the interim government, 
enabling Kira to do his work and travel in Koromira and neighboring areas. According to Denkiung, this formal approval from Bougainville's religious and political leaders strenghtened the OLM. ${ }^{48}$ Its organization became more formal with a secretary, spiritual secretary, spiritual prosecutor, ${ }^{49}$ moderators and members. Denkiung was to bring and explain the word of God to members and make notes during OLM weekly meetings about Kira's inspirations and revelations from Mary and God. ${ }^{50}$ OLM members began to convert people through individual meetings and group workshops, educating, healing, giving sacraments and encouraging people to join the OLM. Thus was created a Marian movementa new community of believers whose model and leader was Mary, the Immaculate Conception.

\section{GLOBAL CONTEXT OF MARIAN DEVOTION IN BOUGAINVILLE}

The Immaculate Conception refers to the Roman Catholic teaching that from the moment Mary herself was conceived (as distinct from Jesus' conception by the Holy Spirit within her), she was kept free of original sin and filled with grace. Various iconographies visualize this dogma, but the statue used by Kira is identical to the image of Mary stamped on mass-produced medals, based on the vision of Saint Catherine Labouré, D.C. (1806-1876). Labouré was a member of the Daughters of Charity of Saint Vincent de Paul and a Marian visionary who conveyed Mary's request to create the "Miraculous Medal," on which the haloed Mary is depicted standing on a serpent with her outstretched hands emitting rays of light. Here, Mary is the Divine Maternity, "crushing the head of the serpent [Satan] and advancing the reign of Christ." 51 This image also is used by the Legion of Mary, a lay Catholic organization founded in Dublin in 1921 and active in the Koromira area from the 1960s. Legionaries regard Mary, the Immaculate Conception, as their worldwide leader. Due to its perceived "cargo cult" characteristics, ${ }^{52}$ the Legion of Mary was quickly banned by the Catholic Diocese of Bougainville. Regardless of this formal denunciation, however, remnants of the Legion persist in the Koromira area. ${ }^{53}$

Kira's call to do the work of Mary also might have been inspired by the so-called Friday Religion founded in 1958 some 7.5 miles inland from Koromira Mission Station. This movement set Friday rather than Sunday as the day of worship. Like the Legion of Mary and the OLM, participants in the Friday Religion regarded the Blessed Virgin as "the centre of all Motherhood, as the spiritual mother of all human bodies and as the mother of all spiritual bodies of the departed." 54

It appears, then, that especially in the Koromira area devotion to Mary has been very much a part of people's lives. Kira's Our Lady of 
Mercy and Ona's Marian Mercy Mission thus can be viewed as part of a longer history of Marian movements and devotion in Bougainville. In fact, it seems that Kira combined the legacies of the Legion of Mary in Koromira, such as the Immaculate Conception and the importance of holiness and Mary's work against sin, with remnants of older Marian movements and other available information on Mary. OLM member Ichnatus Denkiung kept files of the movements' activities, but also about Marian events elsewhere, such as apparations at Medjugorje in former Yugoslavia. Among these papers I found information about Our Lady of Fatima and her three secrets, the first two of which were revealed in 1941 and the third was revealed by the Vatican in 2000. These pamphlets and other information about Mary's activities in the world were important to the ways OLM faithful, and Catholics in general in Bougainville, experienced their faith, as well as their work for Mary. Several persons told me that during the crisis, Mary's apparitions and messages, and her devotees' achievements abroad, strengthened their faith and confirmed that they had chosen the right path. They viewed themselves as part of a larger worldwide Catholic Marian community, and they were inspired to work towards building a holy, Catholic Bougainville nation. ${ }^{55}$

OLM's adoption of the Immaculate Conception and Francis Ona's appropriation of the traveling Our Lady of Fatima statue show how global images of Mary were "nationalized" 56 by associating them with the movements' shared goal of creating an independent and Catholic Bougainville. The OLM envisioned Bougainville as becoming "One, Holi, Katolik, na Apostolik," 57 while Ona's MMM equally envisioned the conversion of the whole of Bougainville to Catholicism.

\section{MARIAN DEVOTION, NATION-BUILDING AND SEGESSIONIST WARFARE}

The Marian Mercy Mission and Our Lady of Mercy movements had strong nationalist and separatist drives, linking faith and holiness with the Bougainville Island's well-being. The OLM encouraged members to follow the laws and conduct of God, thereby strengthening the Bougainville Catholic Church as well as the nation. One OLM circular blamed Papua New Guinea for causing Bougainvilleans to misbehave, stating "the politics of the Papua New Guinean government have been brainwashing people's minds," and that "economic development works [such as the mining] have led people astray and corrupted them." The PNG government also was accused of having brought "all kinds of false [religious] beliefs into Bougainville." 58 The OLM's mission was to enlighten people and lead them to the "Society bilong Santu Maria," ensuring that Bougainvilleans became good Catholics in service to the nation. ${ }^{59}$ The same circular pointed people towards their obligation to 
help others, hence strengthening the work of the Catholic Church in each parish in the diocese, the whole of Bougainville, and the world.

Although I have no evidence of direct interactions between the OLM and the MMM, the former had strong connections with Ona's Bougainville Revolutionary Army (BRA), in particular with BRA groups operating in the Koromira area. In order to gain independence, the BRA fought against the PNGDF and against Bougainvillean groups siding with the PNG government. OLM support for the Bougainville Revolutionary Army was clear: Kira's seven sons were in the BRA, as were many other OLM members' sons, sons-in-law, brothers and husbands. Moreover, a large number of OLM activities centered on proselytizing BRA communities. In 1992 OLM obtained written approval from BRA general Sam Kauona to do the work of the "Society of Mercy," facilitating Kira's and his fellow members' work in BRA camps. ${ }^{60}$ Denkiung recalled: "We visited all BRA camps, giving talks, advising them that this fight was about freedom. We were fighting for our right. So they must fight with the enemy only, not with civilians." 61

When I talked with Kira about OLM's work in BRA camps, he stressed the importance for BRA combatants to have faith:

We went to BRA camps. We told them they must live as Christians. They
must keep their faith and they should improve their belief. They must
stay strong; the faith of Mama Maria must hold them. This faith is like
a tool helping us. When we do not have this tool, we lose faith and it will
be hard to survive. Catholics must always stay close to Mama Maria, else
we will be like orphans who have lost hope and confidence. God is the
answer! ${ }^{62}$

Denkiung's emphasis on just war and Kira's emphasis on faith reveal the entanglement between freedom (independence) and faith. Both the OLM and the MMM strongly emphasized unity and holiness in order to receive help from God and Mary to obtain independence and restore the holy nation of Bougainville. As expressed by Kira: "During the crisis, everyone must stay holy. We must try to become holy so we can go to heaven. Life is risky. Suppose you don't survive. God created us to survive. The BRA stayed through prayer within God's protection." 63 MMM member Maria Dewana conveyed a similar conviction: "Me'ekamui, BRA, they had to stay clean in the fight. They had to be holy. Those who followed Ona, they were clean during the fight and survived. Those who didn't were shot by the PNGDF." 64

The personal call to holiness, a central notion of Catholicism, refers to the belief that people are made one in the unity of the Father, Son and Holy Spirit. The universal call to holiness and apostolate teaches that all people are called to be holy ${ }^{65}$ and spread holiness to others. Holiness is both a state and a task whereby Christians should be "striving for a full Christian life, imitating Christ, the Son of God, who gave his life 
for God and for his neighbor." 66 In addition to this personal call and pursuit of holiness, there is the theological and biblical notion that a whole nation or people can be holy.

The notion of "a chosen race, a royal priesthood, a holy nation" 67 applies to how participants in the OLM, MMM and BRA envisioned themselves and their task. ${ }^{68}$ Former BRA combatant and prayer leader (chaplain) Albert Natee, son-in-law of an active OLM member, explained why and how BRA members had to become holy soldiers:

Francis Ona said this land must become holy again, Me'ekamui. We prayed to God and he gave us strength. This directed us to engage in a clean battle. We were fighting for our rights, to get rid of all these bad companies and their effects. All BRA and all Bougainvilleans, everybody practiced this holiness. We had to stay with the Church. Our spirits had to be holy, so God would get rid of Satan [the mining companies]. We had to stay holy to get rid of it. And God helped us. How? His power worked through the rosary. Before we would go on patrol or go into battle, we would pray the most powerful decades, the Lord's Prayer and Hail Marys. This we did collectively, as a group. The mysteries we would pray in private. We would pray for protection and for guidance. I would get them [BRA fighters] all together and read Bible passages and explain how to stay holy in combat. We stayed holy by not gossiping, not swearing, and not getting angry. When somebody caused trouble in the camp, we would send him away. We had to stay holy! As a group we should stay holy, and one man could not be allowed to destroy this. He would have to make some kind of sacrifice and could return after some weeks. He had to apologize to God, to us, to those to whom he had wronged. If he refused, he would jeopardize our safety. God will not protect us when we have done wrong. Also, when I die, I must go to heaven. So before and during the battles, I had to stay holy so that in case I got shot, I would go straight to heaven. ${ }^{69}$

Many Catholic BRA members took their rosaries to the battlefield as a form of protection (see Figure 2), ${ }^{70}$ but instead of wearing the beads around their necks they tucked them into their pockets. The men were convinced that Mary would prevent them from killing Christian PNGDF soldiers by blocking their automatic weapons. Although they trusted Mary to protect them from getting killed, they were also convinced of Mary's loving nature and her power to prevent any killing. Thus by hiding the beads, the men ensured Mary's protection for their own lives, while they were still able to use their guns and kill their enemies.

Many of the Koromira people I interviewed were convinced that because God was with them during the crisis, nobody was killed or died of sickness. Indeed, the fight to retain Bougainville land and return it to its rightful custodians was perceived as a holy war. ${ }^{71}$ As Paul, an elder of a mountain village, expressed: "During the war, none of our BRA boys died, because they fought with holiness. They did not kill unarmed 


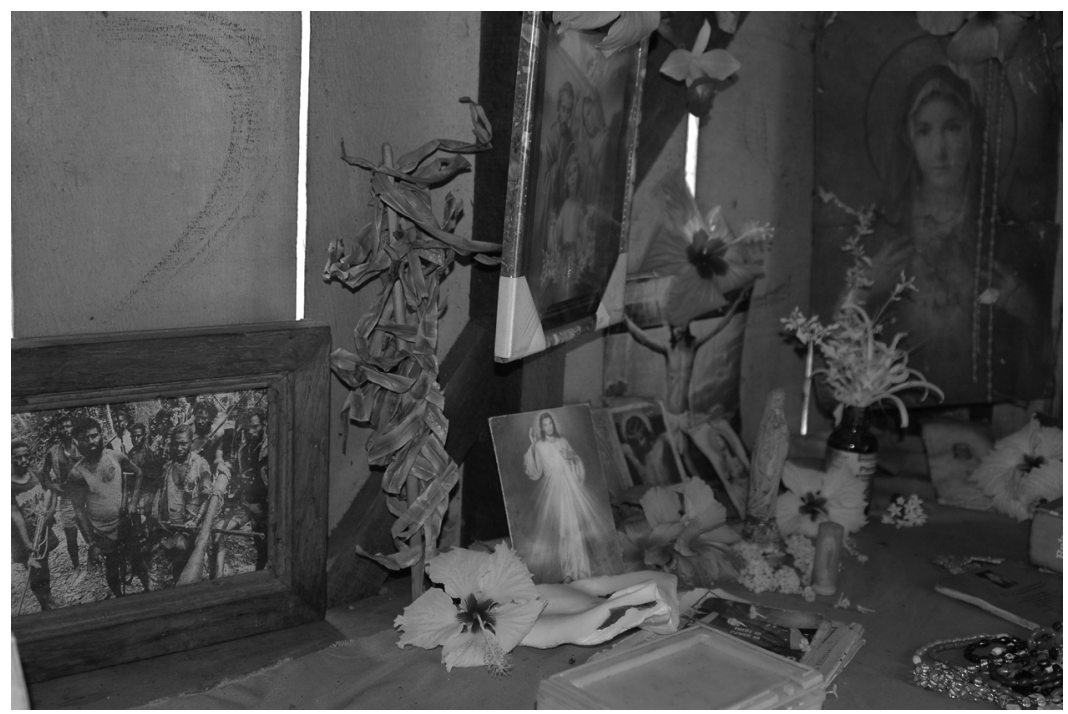

Figure 2. Home altar of Albert Natee in Koromira, Bougainville in 2005. It displays the small statue of Mary he took with him on the battlefield, as well as a copy of a photograph of his BRA comrades and himself during the conflict. Photo courtesy of Anna-Karina Hermkens.

men-only PNGDF. It was a holy war. So before they went into action, they prayed. And God protected them."72

\section{ONA AS KING OF ME'EKAMUI}

The interplay between Marian devotion and resistance was very much present in Francis Ona's fight for Bougainville independence and the sense of personal divine authority with which he sought to legitimate and enhance his leadership of Me'ekamui. ${ }^{73}$ From land defender and rebel Ona became a patriot-hero, inspiring and mobilizing people to fight against occupying forces. In 1990 the Bougainville Interim Government was established as the legitimate local authority, with Francis Ona as President and Joseph Kabui as Chair. On 17 May 1990, it declared Bougainville independent from Papua New Guinea. The warfare continued until the ceasefire in 1998, which was followed by the 2001 Peace Agreement making Bougainville an autonomous region of Papua New Guinea. A year prior to the first election of the Autonomous Bougainville Government and President in May and June 2005, Ona proclaimed himself His Royal Highness King Francis Dominic Dateransy Domanaa, King of the Royal Kingdom of Me'ekamui, in May 2004. ${ }^{74}$ Although his crowning was met with apprehension and mockery 


\section{Nova Religio}

by members of the public, many of his adherents—especially those calling themselves Me'ekamui-perceived him to be their king.

Ona's crowning as King of Me'ekamui can be seen as an assertion of his power and authority against the Autonomous Bougainville Government (ABG). In 2005, when Ona went to south Bougainville in anticipation of the upcoming elections, a man asked him, "Shouldn't you step down now that we have the ABG?" Ona answered, "I am not a King of the government; I am the King of all grasshoppers, trees, oil, minerals, of everything that is on this island. When I step down, our island will go down," destroyed by the mining activities of Papua New Guinea and the whites. Ona maintained that a monarchy would open up the isolated and largely ignored holy island of Bougainville and its king to the outer world: "I've got people all over the world supporting me as a monarch. We've got a monarchical system in which different kingdoms support each other, so all the monarchies are willing to give me our much-needed aid."75

Ona's crowning also should be viewed in light of its biblical connotations. Both God and human political leaders are referred to as king in the Old Testament. With their God-given title, biblical kings reigned over dominions with unrestricted power. This link between divine sanction and political leadership was expressed in Bougainville and disseminated when people began to refer to Ona in terms of holy leadership. In fact, in 2006 on the occasion of the first anniversary of Ona's death on 24 July 2005, Bernard Unabali, then Auxiliary Bishop of Bougainville, described him as "a Savior of Bougainville" who, like Moses in the Bible, led the Bougainvilleans to freedom. ${ }^{76}$

It seems, however, that Ona's royal authority was appreciated only by those living close to him and/or who had unlimited faith in his divinely inspired abilities. Outside his empire, Ona's kingship was met with criticism and even laughter. During the crisis, he had failed to be a strong leader, unable to control vigilante groups both within and outside the BRA. Moreover, his refusal to come down from his hideout in the Panguna Mountains or participate in peace negotiations contributed to his fading support and lack of political power in the wider region. However, only weeks before the 2005 Autonomous Bougainville Government elections, Ona came down from the mountain, surprising both followers and opponents with a strong, convincing public speech and presentation. We will never know to what extent he would have been able to contest the secular Autonomous Bougainville Government, since his unexpected death a few months later ended his career as king of Me'ekamui.

\section{CONGLUSION}

Since Ona's death in 2005 the Marian Mercy Mission movement seems to have lost its driving and uniting force and is slowly fading away. 
Likewise, Our Lady of Mercy members complain that since the crisis ended many people have lost faith. A somewhat desolate 65-year-old Peter Kira related in 2005:

Plenty [of] people have lost their rosary and lost faith. All my [seven] sons were in the BRA. They were not hurt, they all stayed good, but now, they are all over the place. One son left me and joined another church, the Christian Life Community. During the crisis we prayed the rosary and it kept us from harm. We asked her, the main thing: to bring peace, to protect and guide our families. After the crisis, we faced many problems.... My children are losing faith. As for me, Maria is my spiritual mother. I really need her. She is the mother of the human race. I cannot lose Maria, she is my true mama. I am a sinful man, I cannot lose her.... I cannot lose them [the mysteries]. I must meet my mother in heaven. . . ${ }^{77}$

Although on a personal level people like Kira remain devoted to Mary, the two Marian movements that played key roles during the crisis have lost their strength and momentum. Perhaps the new social conditions in Bougainville-peace, an autonomous government, and the return of normalcy (work, school and other daily activities) - do not require the intense religious commitment leaders and participants manifested during the crisis. As many of my interlocutors remarked, their faith in Mary was strongest during the crisis when the hardships they faced were at their worst. It thus seems that during the Bougainville crisis, as elsewhere in the world, Marian devotion became a strategy for coping and survival. ${ }^{78}$ Intense faith in Mary during the crisis was also an integral part of an "ideology of resistance," 79 which envisioned a better and more just future in a One, Holi, Katolik, na Apostolik Bougainville. As soon as this political resistance was no longer needed, or lost its credibility (as in the case of Ona), the Marian Mercy Mission and Our Lady of Mercy movements lost their appeal. However, faith in Mary and God has not disappeared in Bougainville. Everyone is convinced it was divine intervention that kept them alive during the crisis, thereby enabling them to be part of the new social and political order of Bougainville today.

I thank the Netherlands Organization for Scientific Research for financial support, and Radboud University, Nijmegen and the Australian National University in Canberra for institutional support.

\section{ENDNOTES}

${ }^{1}$ Bougainville consists of predominantly matrilineal societies. Ona portrayed himself as a landowner, but his female relatives, such as his sisters, were the real landowners. 


\section{Nova Religio}

2 Anthony Regan, The Bougainville Conflict: Origins and Development, Main 'Actors,' and Strategies for Its Resolution (Port Moresby: Faculty of Law, University of Papua New Guinea, 1996), 71.

3 Andy Carl and Lorraine Garasu, "Chronology," in Weaving Consensus: The Papua New Guinea-Bougainville Peace Process [Special Issue], Accord: An International Review of Peace Initiatives, no. 12 (2002): 96, available at www.c-r.org/accord/png\%E2\% $80 \%$ 93bougainville. Accord is a publication series from Conciliation Resources in London. This issue was edited by Andy Carl and Lorraine Garasu.

${ }^{4}$ John Dademo Waiko, A Short History of Papua New Guinea (South Melbourne: Oxford University Press, 1993), 240.

${ }^{5}$ The colonial and recent histories of Bougainville show the impact and different kinds of oppression by white missionaries, plantation owners and colonial administrators. See Douglas Oliver, Black Islanders: A Personal Perspective of Bougainville 1937-1991 (Melbourne: Hyland House, 1991), 21-56; Hugh Laracy, Marists and Melanesians: A History of Catholic Missions in the Solomon Islands (Canberra: Australian National University, 1976), 37.

${ }^{6}$ Patrick F. Gesch, “'We Have Our Own Ways Too': The Dilemma of Reconstruction on Bougainville," Contemporary PNG Studies: DWU Research Journal 2 (May 2005): 93-102, quotation on 95.

7 Tony Swain and Garry Trompf, The Religions of Oceania (London: Routledge, 1995), 182. It is also called the "Fifty Toea Movement," a reference to the monetary contributions members made. See Anthony Regan, "Bougainville: Beyond Survival," Cultural Survival Quarterly 26, no. 3 (2002): 20-24.

${ }^{8}$ Carl and Garasu, "Chronology," 96.

9 Peter Sohia, "Early Interventions," Accord, no. 12 (2002): 16-23.

${ }^{10}$ Swain and Trompf, in their Religions of Oceania, 182, underscore the importance of the "Fifty Toea Movement" in the opposition against Bougainville Copper Ltd.

${ }^{11}$ Simon Kenema, "An Analysis of Post-Conflict Explanations of Indigenous Dissent Relating to the Bougainville Copper Mining Conflict, Papua New Guinea," eJournal of the Australian Association for the Advancement of Pacific Studies 1, no. 2 and 2, no. 1 (April 2010), para. 32, at intersections.anu.edu.au/ pacificurrents/kenema.htm.

12 Anna-Karina Hermkens, "Circulating Matters of Belief: Engendering Marian Movements during the Bougainville Crisis," in Flows of Faith: Religious Reach and Community in Asia and the Pacific, ed. Lenore Manderson, Wendy Smith, and Matt Tomlinson (New York: Springer, 2012), 171-72.

13 Bronwen Douglas, "Power, Discourse and the Appropriation of God: Christianity and Subversion in a Melanesian Context," History and Anthropology 9, no. 1 (1995): 57.

${ }^{14}$ Cathelijne De Busser and Anna Niedzwiedz, "Mary in Poland: A Polish Master Symbol," in Moved by Mary: The Power of Pilgrimage in the Modern World, ed. AnnaKarina Hermkens, Willy Jansen, Catrien Notermans (Farnham, U.K.: Ashgate, 2009), 87-100. In addition to being part of national resistance, particular types of Marian iconography have become national symbols, such as Our Lady of Częstochowa in Poland and Our Lady of Guadalupe in Mexico. See Eric 
R. Wolf, "The Virgin of Guadalupe: A Mexican National Symbol," Journal of American Folklore 71, no. 279 (1958): 34-39.

15 The research on which this article is based was mainly in Arawa, Tunuru, Koromira and Buin (see Figure 1).

${ }^{16}$ Swain and Trompf, Religions of Oceania, 181-82. See also Max Rimoldi and Eleanor Rimoldi, Hahalis and the Labour of Love: A Social Movement on Buka Island (Oxford: Berg Publishers, 1992).

17 Anthony J. Regan, "Bougainville: Beyond Survival," Cultural Survival Quarterly 26, no. 3 (Fall 2002): para. 22, at www.culturalsurvival.org/ourpublications/csq/ article/bougainville-beyond-survival.

18 Regan, "Bougainville," para. 22.

19 Garry W. Trompf, Payback: The Logic of Retribution in Melanesian Religions (Cambridge: Cambridge University Press, 1994), 354.

${ }^{20}$ Laracy, Marists and Melanesians, 54-55.

21 The United Church in Papua New Guinea (UCPNG), including Bougainville, is an amalgation of various mission bodies, including the London Missionary Society, the Australian Methodist Church, the mission of the Presbyterian Church in New Zealand, and the Papua Eklesia. See ucpng. com/about/, accessed 5 February 2015.

${ }^{22}$ Slightly less than one percent self-identified as non-Christian; another two percent did not indicate a religion. See 2000 National Census: North Solomons Provincial Report (Port Moresby, PNG: National Statistical Office, 2002), 19.

23 Some Bougainvilleans did not agree with the new spiritual powers introduced by the Marists, perceiving the Catholic saints as disrupting the traditional spiritual power balance and order. See James Tanis, "Reconciliation: My Side of the Island," Accord, no 12 (2002): 58-61. Others converted to Methodism or Seventhday Adventism, thereby causing religious divisions in areas where people previously had converted to Catholicism. See Eugene Ogan, "The Bougainville Conflict: Perspectives from Nasioi," State, Society and Governance in Melanesia Project, Research School of Pacific and Asian Studies, Australian National University, Discussion Paper 99/3 (1999): 3.

${ }^{24}$ See Hermkens, "Religion in War And Peace: Unraveling Mary's Intervention in the Bougainville Crisis," Culture and Religion 8, no. 3 (2007): 271-89.

25 Mary-Louise O'Callaghan, Enemies Within: Papua New Guinea, Australia and the Sandline Crisis, The Inside Story (Sydney: Doubleday, 1999), 17.

${ }^{26}$ Lawrence McCane, Melanesian Stories: Marist Brothers in Solomon Islands and Papua New Guinea 1845-2003 (Madang, PNG: Divine Word University, 2004), 126.

27 McCane, Melanesian Stories, 339; see also L. J. Daveona, "Francis (Dateransi) Ona: A Rebel with a Cause," 2006, at www.friends-of-bougainville.com/admin/ ktmlpro10/data/public_uploads/downloads/F_O_UROLOGY.pdf; accessed 9 October 2007, now defunct.

28 Daveona, "Francis (Dateransi) Ona."

29 Anthony Regan, Light Intervention: Lessons from Bougainville (Washington, D.C.: United States Institute for Peace, 2010), 19; Karl Claxton, Bougainville 1988-98: Five Searches for Security in the North Solomons Province of Papua New Guinea, 


\section{Nova Religio}

Canberra Papers on Strategy and Defence no. 130 (Canberra: Strategic and Defence Studies Centre, Research School of Pacific Studies, Australian National University, 1998), 82-83.

${ }^{30}$ Claxton, Bougainville 1988-98, 83.

31 Bishop Henk Kronenberg, S.M., interview with author, 15 and 25 October 2005. Bishop Emeritus Kronenberg retired as bishop of Bougainville in December 2009 and was succeeded by Bougainvillean Bishop Bernard Unabali. ${ }^{32}$ Maria Dewana (MMM member), interview with the author, 7 November 2005.

${ }^{33}$ Father Luis Lovosi, interview with the author, 26 October 2005.

${ }^{34}$ In September 1994 PNG Prime Minister Sir Julius Chan met with BRA commander Sam Kauona in Honiara. The talks culminated in the Honiara Commitment to Peace and the Ceasefire Agreement, paving the way for creation of a neutral zone for the Arawa Peace Conference. See Sohia, "Early Interventions," 21.

35 Father Luis Lovosi, interview with the author, 26 October 2005.

${ }^{36}$ Father Bernard Unabali, interview with the author, 19 October 2005.

${ }^{37}$ Father Luis Lovosi, interview with the author, 26 October 2005.

38 Maria Dewana, interview with the author, 7 November 2005.

${ }^{39}$ See Hermkens, "Mary's Journeys through the Warscape of Bougainville," in Hermkens, Jansen, Notermans, Moved by Mary, 69-85.

40 One year later, on 30 April 1998, the crisis officially ended when all parties signed a ceasefire agreement. Ona was absent, having stayed out of the peace process. The BRA was represented by leaders Sam Kauona and Joseph Kabui. Hostilities between various Bougainville groups continued, but among Catholics there is now general conviction that the pilgrimage of the Our Lady of Fatima statue marked a turning point in the crisis.

41 The unreleased film titled "Pilgrim of Peace" was made in 1997 by Father Zdzislaw Mlak of the Religious Television Association (RTA) in Port Moresby, Papua New Guinea.

${ }^{42}$ See Hermkens, "Circulating Matters of Belief," 161-81. In this chapter, I focus on the circulation of objects and pamphlets in the establishment of Peter Kira's Our Lady of Mercy movement.

${ }^{43}$ Peter Kira, interview with the author, 12 December 2005.

${ }^{44}$ Bishop Gregory Singkai, who had innovative ideas for the Catholic Church on Bougainville, died unexpectedly in September 1996, causing rumors, suspicion concerning the cause of his death, and the establishment of cults surrounding his remains and ideas. He is still popular among Bougainvilleans, and his ideas permeate teaching curricula and religious movements.

${ }^{45}$ Peter Kira, interview with the author, 12 December 2005.

${ }^{46}$ Ichnatus Denkiung, interview with the author, 25 November 2005.

${ }^{47}$ Ichnatus Denkiung, interview with the author, 25 November 2005.

${ }^{48}$ Ichnatus Denkiung, interview with the author, 25 November 2005.

49 Someone who represents the "government" of God in charging Satan with a spiritual "crime." 
${ }^{50}$ Ichnatus Denkiung, interview with the author, 25 November 2005.

${ }^{51}$ Bede McGregor, The Official Handbook of the Legion of Mary (Dublin: De Montfort House, Concilium Legionis Mariae, 2005), 12.

52 The term "cargo cult" has often been used to describe Melanesian movements occurring typically in the wake of contact with commercial networks of colonizing societies in which people expect the imminent arrival of ancestors or Jesus Christ bringing wealth in the form of cargo. See Garry W. Trompf, "New Religious Movements in Oceania," in this issue of Nova Religio; and Trompf, "Pacific Millennial Movements" in The Oxford Handbook of Millennialism, ed. Catherine Wessinger (New York: Oxford University Press, 2011), 435-53.

53 Father Bernard Unabali, interview with the author, 19 October 2005.

${ }^{54}$ G. W. Trompf, Melanesian Religion (Cambridge: Cambridge University Press, 2004), 228-29.

${ }^{55}$ Hermkens, "Circulating Matters of Belief," 171.

${ }^{56}$ David Morgan, The Sacred Gaze: Religious Visual Culture in Theory and Practice (Berkeley: University of California Press, 2005), 151, 170-71.

${ }^{57}$ Circular, n.d., OLM archives, Siriwai village, Bougainville.

58 Circular, n.d., OLM archives, Siriwai village, Bougainville. Translation from Tok Pidgin into English by the author.

${ }^{59}$ Hermkens "Circulating Matters of Belief," 172.

${ }^{60}$ Hermkens "Circulating Matters of Belief," 172.

${ }^{61}$ Ichnatus Denkiung, interview with the author, 25 November 2005.

${ }^{62}$ Peter Kira, interview with the author, 12 December 2005.

63 Peter Kira, interview with the author, 12 December 2005.

${ }^{64}$ Maria Dewana, interview with the author, 7 November 2005.

65 Pope Paul VI, Lumen Gentium, 21 November 1964, Chapter V, at www.vatican. va/archive/hist_councils/ii_vatican_council/documents/vat-ii_const_196411 21_lumen-gentium_en.html.

${ }^{66}$ John Paul II, Apostolic Letter Novo Millennio Ineunte, 6 January 2001, at www. vatican.va/holy_father//john_paul_ii/apost_letters/documents/hf_jp-ii_apl_ 20010106_novo-millennio-ineunte_en.html.

67 This phrase is found in 1 Peter 2:9-10. See also Lumen Gentium, Chapter II.

68 Hermkens, "Circulating Matters of Belief," 173.

${ }^{69}$ Albert Natee, interview with the author, 22 November 2005.

${ }^{70}$ In various areas in Papua New Guinea, wearing a rosary is believed to protect oneself, or one's children, against raskols (gangs of armed criminals) or other evil.

71 Elizabeth Ibua Momis, "The Bougainville Catholic Church and 'Indigenisation,"' in Bougainville: Before the Conflict, ed. Anthony J. Regan and Helga M. Griffin (Canberra: Pandanus Books, 2005), 326.

72 Paul John Kaanama, interview with the author, 21 November 2005.

73 See Hermkens, "The Power of Mary in Secessionist Warfare," in Powers: Religion as a Social and Spiritual Force, ed. Meerten B. ter Borg and Jan Willem van Henten (New York: Fordham University Press, 2010), 116-33. 


\section{Nova Religio}

${ }^{74}$ Regan, Light Intervention, 112-13, reveals it was Noah Musingku, operator of a fraudulent investment scheme, who persuaded Ona to transform the Republik of Me'ekamui into the Royal Kingdom of Me'ekamui with Ona as king.

${ }^{75}$ Shane McLeod, "Bougainville-The Man Who Would Be King," Foreign Correspondent, 17 May 2005, at www.abc.net.au/foreign/content/2005/s1372 909.htm.

76 “Ona's Legacy Still Lives,” Post Courier, 4 August 2006.

77 Peter Kira, interview with the author, 12 December 2005.

${ }^{78}$ See various chapters in Hermkens, Jansen, Notermans, Moved by Mary, which detail how Marian devotion is especially practiced by and popular among those who are suffering from gender, power and economic inequalities. See also Hermkens, "Becoming Like Mary: Coping with Domestic Violence in Urban Papua New Guinea," in Engendering Violence in Papua New Guinea, ed. Margaret Jolly, Christine Stewart, and Carolyn Brewer (Canberra: Australian National University Press, 2012), 137-61.

79 Douglas, "Power, Discourse and the Appropriation of God," 57. 